\title{
AVALIAÇÃO DA SIMILARIDADE GENÉTICA ENTRE OS ACESSOS DE Parkia Platycephala POR MEIO DE MARCADORES ISSR
}

\section{Raiane de Sousa Oliveira ${ }^{1}$, Maria Fernanda Costa Gomes ${ }^{2}$, Raimundo Bezerra Araújo Neto ${ }^{3}$, Francielle Alline Martins ${ }^{4}$, Paulo Sarmanho da Costa Lima ${ }^{5}$}

\author{
${ }^{1}$ Graduanda em Bacharelado em Ciências Biológicas, Universidade Estadual do Piauí, UESPI, Teresina - PI, Fone: (86) \\ 3221-4948, raianedp2012@hotmail.com. \\ ${ }^{2}$ Doutoranda em Ciências Biológicas, Universidade Federal de Pernambuco, UFPE, Recife-PE, Fone: (81) 2126-8000, \\ fernanda_mf2@hotmail.com. \\ ${ }^{3}$ Pesquisador da Empresa Brasileira de Pesquisa Agropecuária, EMBRAPA, Teresina - PI, Fone: (86) 3198-0500, \\ raimundo.bezerra@embrapa.com. \\ ${ }^{4}$ Doutora em Genética e melhoramento, Prof a Adjunto III, Depto. De Ciências da Natureza, Universidade Estadual do Piauí, \\ UESPI, Teresina - PI, Fone: (86) 3213-7887, profafrancielle@yahoo.com.br. \\ ${ }^{5}$ Doutor em Genética e melhoramento de plantas, Pesquisador A, Empresa Brasileira de Pesquisa Agropecuária, EMBRAPA, \\ Teresina - PI, Fone: (86) 3089-9192, paulo.costa-lima@embrapa.br.
}

RESUMO: Parkia platycephala Benth. é uma espécie pertencente à família Leguminosae, cuja ocorrência abrange a Região Nordeste do Brasil. Destaca-se pelo seu potencial madeireiro, paisagístico e, principalmente, como forrageira. Tal exploração tem gerado a perda da variabilidade genética dessa espécie. O objetivo do estudo foi avaliar a similaridade genética entre os acessos de P. platycephala do Banco de Germoplasma da Embrapa MeioNorte (PI) por meio de marcadores ISSR. Para extração do DNA, amostras de 10 folhas jovens foram coletadas no Banco de Germoplama (BAG) da EMBRAPA Meio-Norte foram utilizadas e quantificadas em gel de agarose $0,8 \%$. As amostras de DNA foram amplificadas com 05 primers ISSR, gerando 44 locos, dos quais 37 foram polimórficos. A similaridade entre os acessos foi baseada no índice de similaridade de Jaccard, gerando um dendrograma composto por dois grupos, sendo os acessos F-01, F-02 e F-03 os mais divergentes dos demais. Os marcadores moleculares ISSR foram eficientes na caracterização dos acessos de $P$. platycephala analisados e representam uma ferramenta útil para o estudo da diversidade. PALAVRAS-CHAVE: Faveira, diversidade genética, forrageira

\section{EVALUATION OF GENETIC SIMILARITY BETWEEN PARKIA PLATYCEPHALA ACCESSES BY ISSR MARKERS}

\begin{abstract}
Parkia platycephala Benth. is a species belonging to the family Leguminosae; its occurrence covers the Northeastern Brazil. It stands out for its wood potential, landscaping and, mainly, as fodder. This exploration has generated the loss of the genetic variability of this species. The objective of the present study was to evaluate the genetic similarity between $P$. platycephala accesses of Embrapa Mid-North (PI) Germplasm Bank through ISSR markers. For DNA extraction, samples of 10 young leaves collected in the Embrapa MidNorth BAG were used and quantified in agarose gel $0.8 \%$. They were amplified with 05 ISSR primers, generating 44 loci, of which 37 were polymorphic. The similarity between the accesses was based on Jaccard's similarity index, generating a dendrogram composed of two groups, with F-01, F-02 and F-03 access being the most divergent of the others. ISSR molecular markers were efficient in the characterization of P. platycephala accesses analyzed and represent a useful tool for the study of diversity.
\end{abstract}

KEYWORDS: Faveira, genetic variability, forage 


\section{INTRODUÇÃO:}

Parkia platycephala Benth,. conhecida como faveira de bolota, é uma espécie pertencente à família Leguminosae. Sua ocorrência abrange a Região Nordeste do país, em áreas de transição entre Cerrado ou Mata Atlântica para a Caatinga. Destaca-se pelo seu potencial madeireiro, pois a mesma é utilizada na fabricação de caixotes, tabuados para divisões internas em pequenas construções, forros, confecção de brinquedos, bem como para lenha e carvão. Além disso, e apresenta grande potencial para uso paisagismo e, principalmente, como forragem, onde as vagens quando maduras constituem excelente fonte de alimentação para ruminantes (ALVES et al., 2007). A utilização da espécie é de grande importância para o semiárido nordestino, pois à mesma é um dos principais suportes forrageiros para a produção animal, sendo utilizada em diversos Estados do Nordeste, principalmente no período de seca, pois os solos da região são rasos, com baixa fertilidade natural e uma vegetação rala. No contexto da produção animal, essas características implicam um aumento do custo de produção, devido à indisponibilidade de forragens de qualidade durante todo o ano, constituindo o maior entrave no desenvolvimento da pecuária regional. Isso leva os produtores ou pecuaristas a investir na produção, armazenamento e conservação de forragens para suprir a necessidade alimentar do rebanho no período seco, onde o alimento é bastante escasso (CARVALHO et al., 2006). Os frutos coletados na época da safra, aliada à fragmentação dos ecossistemas florestais, tem gerado a perda da variabilidade genética de muitas espécies florestais nativas de elevado potencial econômico e ambiental (SATO et al., 2008).

Um passo muito importante para promover estratégias de conservação dos recursos genéticos é a verificação da diversidade genética desses materiais de interesse econômico. É através dessa informação que programas de melhoramento genético permitem selecionar acessos divergentes possibilitando cruzamentos promissores (SANTANA et al., 2016). $\mathrm{O}$ acesso a essa variação genética pode ser por meio de marcadores moleculares, que revelam polimorfismo ao nível de DNA e não sofrem influência ambiental (KUMAR et al., 2009). Dentre os marcadores moleculares, o ISSR (Inter-simple sequence repeats) é bastante usado nos estudos de diversidade, pois o mesmo tem a vantagem de gerar grande número de sequências informativas por reação (sequências polimórficas), principalmente, em organismos pouco estudados, como faveira de bolota (VELEZ et al., 2016). Portanto, o objetivo do presente estudo foi avaliar a similaridade genética entre acessos de Parkia platycephala do Banco de Germoplasma da Embrapa Meio - Norte (PI) por meio de marcadores ISSR. 


\section{MATERIAL E MÉTODOS}

A pesquisar foi conduzido a partir de 10 acessos de Parkia platycephala Benth. coletados no Banco de Germoplasma, localizado na Embrapa Meio - Norte (PI). As folhas de faveira de bolota coletadas foram embaladas em papel toalha e colocadas dentro de sacos plásticos e, em seguida, armazenadas a $-20^{\circ} \mathrm{C}$, até o momento da extração do DNA. Para a extração, as folhas foram maceradas em Precellys- 6600rpm (2x 25-30) até a obtenção de um pó fino. A extração foi realizada segundo o protocolo de Doyle e Doyle (1990). As amostras foram quantificadas por eletroforese em gel de agarose $0,8 \%$, utilizando como padrão quantidades conhecidas do DNA do Fago $\lambda(100 \mathrm{ng}$ ). A qualidade das amostras foi estimada por meio de espectrofotômetro NanoDrop 2000 (Thermo Scientific). O DNA obtido foi armazenado em freezer, a $-20^{\circ} \mathrm{C}$, até a realização das reações de amplificação. Foram selecionados 05 primers ISSR, desenvolvidos pela University British of Columbia, de acordo com o nível de polimorfismo e resolução das bandas. As reações de PCR foram conduzidas em volume final de $10 \mu \mathrm{L}$, contendo, para cada amostra: 7 ng de DNA, $6,8 \mu \mathrm{L}$ de água, $1 \mu \mathrm{L}$ de dNTP (10mM), $1 \mu \mathrm{L}$ de Buffer (10X), 0,3 $\mu \mathrm{L}$ de $\mathrm{MgCl} 2(50 \mathrm{mM}), 0,3 \mu \mathrm{L}$ de primer e $0,5 \mathrm{U}$ de Taq DNA polimerase $(5 \mathrm{U} / \mu \mathrm{L})$. O programa de amplificação para as reações consistiu de uma desnaturação inicial do DNA a $94^{\circ} \mathrm{C}$ durante 1 minuto e 30 segundos, seguido de 40 ciclos a $94^{\circ} \mathrm{C}$ por 40 segundos, Ta por 45 segundos e $72^{\circ} \mathrm{C}$ por 2 minutos, e uma extensão final de $72^{\circ} \mathrm{C}$ por 7 minutos. As temperaturas de anelamento (Ta) variaram de acordo com o especificado para cada primer. Os fragmentos gerados por cada reação de amplificação foram separados por eletroforese em gel de agarose $(1,5 \%)$ com TBE $0,5 \mathrm{X}$ durante quatro horas a 110 V. Os géis foram corados com GelRedTM (Biotium) e fotodocumentados sob luz ultravioleta. Para facilitar a genotipagem dos dados, em cada gel foi aplicado dois marcadores de peso molecular conhecido, $1 \mathrm{~Kb}$ (Invitrogen) e 100bp (Invitrogen). A partir dos fragmentos amplificados, construiu-se uma matriz binária onde a presença e ausência da banda foram representadas, respectivamente, por 1 e 0 . A partir da matriz de similaridade genética, construiu-se o dendrograma pelo método de agrupamento UPGMA (Unweighted Pair Group Method with Arithmetic Mean), com um índice de confiabilidade bootstrap de 1000 repetições e o coeficiente de correlação cofenética (r), realizadas por meio do programa PAST v. 3.08 (HAMMER et al., 2001).

\section{RESULTADOS E DISCUSSÃO}

As temperaturas de anelamento selecionadas para os primers UBC-808, UBC-810, UBC-811, UBC-812 e UBC-818 foram $50^{\circ} \mathrm{C}, 52^{\circ} \mathrm{C}, 50^{\circ} \mathrm{C}, 49^{\circ} \mathrm{C}$ e $50^{\circ} \mathrm{C}$, respectivamente, 
amplificando fragmentos de DNA nítidos, bem definidos e polimórficos nas amostras de $P$. platycephala (Figura 1)

KB F01 F02 F03 F04 F05 F06 F07 F08 F09 F10 B 100bp

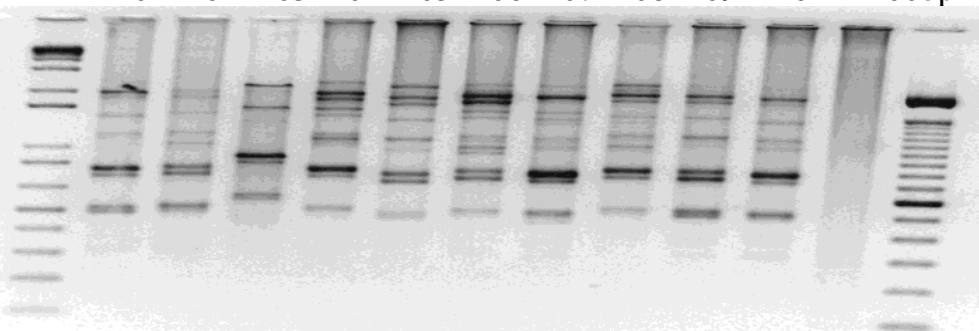

Figura 1. Gel de agarose dos produtos de amplificação gerados pelo primer UBC-818. Para cada primer foi utilizado o DNA de 10 amostras de $P$. platycephala. A primeira coluna (KB) indica o DNA ladder de $1 \mathrm{~Kb}$ e a última 100Bp.

*F01 a F10: amostras de faveira de bolota; B: branco

A partir dos 05 primers selecionados obteve-se um total de 44 locos amplificados, dos quais 37 foram polimórficos, o que representa $79 \%$ de polimorfismo. O maior número de bandas foi obtido pelo primer 808 (12), enquanto o menor pelos primers 810,811 e 812 com 6,7 e 8, respectivamente; com média de 8,8 locos gerados por primer. O tamanho dos fragmentos variou de 200 a 2000 pb (Tabela 1).

Tabela 1. Locos amplificados e polimorfismo em cada um dos primers selecionados.

\begin{tabular}{ccccc}
\hline \multirow{2}{*}{ Primers } & \multicolumn{2}{c}{ Locos } & $\begin{array}{c}\text { Polimorfismo } \\
(\%)\end{array}$ & Amplitude das Bandas $(\mathrm{pb})$ \\
\cline { 2 - 3 } & Total & Polimórficos & $(100,0$ & $500-2000$ \\
808 & 12 & 12 & 83,3 & $400-1650$ \\
810 & 6 & 5 & 62,5 & $200-1000$ \\
811 & 8 & 5 & 85,7 & $500-1650$ \\
812 & 7 & 6 & 63,6 & $500-1650$ \\
818 & 11 & 7 & 79 & $200-2000$ \\
\hline Total & 44 & 37 & &
\end{tabular}

A partir da matriz de similaridade obteve-se o dendrograma pelo método UPGMA. O alto valor obtido da correlação cofenética $(r)$ 0,75 indica que há correlação entre a matriz de similaridade e o dendrograma. Identificou-se a formação de dois grupos geneticamente distintos que surgem a partir da distância de 0.56, sendo que os acessos do grupo I apresentaram maior similaridade, destacando-se (F-08 e F-10). O grupo II está representado pelos três acessos de faveira (F01, F02 e F03) e representam o grupo mais divergente dos demais (Figura 2). 


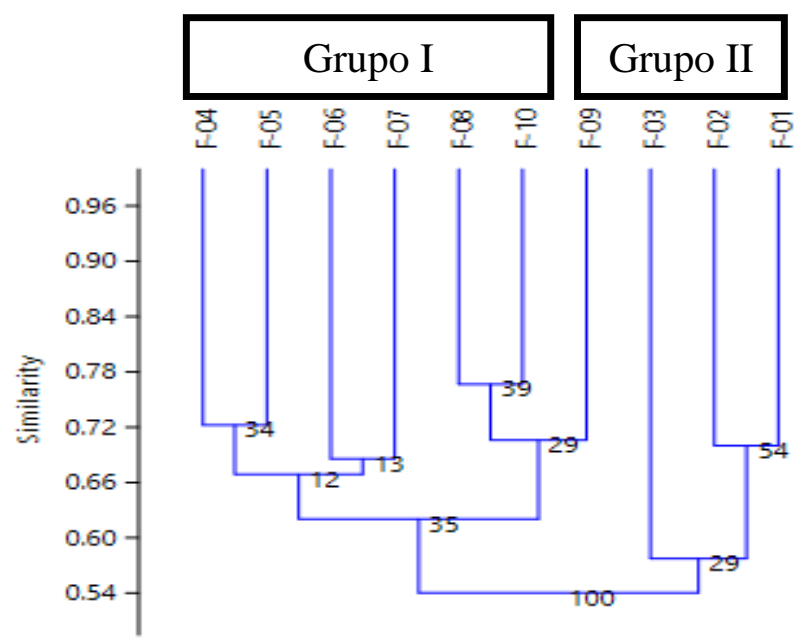

Figura 2. Dendrograma gerado pelo método UPGMA baseado no índice de similaridade de Jaccard entre os 10 acessos de $P$. platycephala Benth provenientes do BAG da Embrapa Meio-Norte (PI).

\section{CONCLUSÕES}

Os marcadores moleculares ISSR foram eficientes na caracterização dos acessos de $P$. platycephala analisados e representam uma ferramenta útil para o estudo da diversidade genética em faveira. Os acessos F-01, F-02 e F-03 foram os mais divergentes dentro do grupo analisado.

\section{AGRADECIMENTOS}

À Embrapa Meio-Norte pelo suporte técnico necessário à realização do trabalho.

\section{REFERÊNCIAS:}

ALVES, A. A. et al. Degradabilidade ruminal in situ de vagens de faveira (Parkia platycephala Benth.) em diferentes tamanhos de partículas. Revista Brasileira de Medicina Veterinária e Zootecnia, v.59, n.4, p.1045-1051, 2007.

DOYLE, J. J.; DOYLE, J. L. Isolation of plant DNA from fresh tissue. Focus, v. 12, p. 13-15, 1990.

HAMMER, Ø.; HARPER, D. A. T.; RYAN, P. D. PAST: Paleontological Statistics software package for education and data analysis. Paleontologia Electronica, v. 4, n. 1, p. 1-9, 2001. 
CARVALHO, G. M. C; ALMEIDA, M. J.; ARAUJO NETO, R.B.; OLIVEIRA, F.C.Produção de feno no Semi-Árido. 1.ed Teresina: Embrapa Meio-Norte, 2006. 33 p.

KUMAR, P.; GUPTA, V, K.; MISRA, A. K.; D. R. MODI; D. R.; PANDEY, B. K. Potential of molecular markers in plant biotechnology. Plant Omics, v. 2, n. 4, p.141-162, 2009.

SANTANA, J. G. S.; NASCIMENTO, A. L. S.; COSTA, T. S.; ALMEIDA, T. M. B.; RABBANI, A. R. C.; SILVA, A. V. C. Estimation of genetic diversity in a natural population of Cambuí tree (Myrciaria tenella O. Berg) using ISSR markers. Genetics and Molecular Research, v. 15, n. 4, p. 1-11, 2016.

SATO, A. S.; LIMA, I. L.; TONIATO, M. T. Z.; ZIMBACK, L. Crescimento e sobrevivênvia de duas procedências de Aspidosperma polyneuron em plantios experimentais em Bauru, SP. Revista do Instituto Florestal, v. 20, n.1, p. 23-32, 2008.

VELEZ, P.; QUINTERO, C. A.; MERINO, G.; GASCA-PINEDA, J.; GONZÁLEZ, M. C. An ISSR-based approach to assess genetic diversity in the marine arenicolous fungus Corollospora maritime sensu lato. Mycoscience, v. 57, p. 187-195, 2016. 